\title{
Exploring Students' Views in the Use of Quizizz as an Assessment Tool in English as a Foreign Language (EFL) Class
}

\author{
Siti Zuhriyah, Bambang Widi Pratolo* \\ Master Program of English Language Education, Universitas Ahmad Dahlan, Indonesia
}

Received July 13, 2020; Revised August 20, 2020; Accepted September 17, 2020

\begin{abstract}
Cite This Paper in the following Citation Styles
(a): [1] Siti Zuhriyah, Bambang Widi Pratolo , "Exploring Students' Views in the Use of Quizizz as an Assessment Tool in English as a Foreign Language (EFL) Class," Universal Journal of Educational Research, Vol. 8, No. 11, pp. 5312 - 5317, 2020. DOI: 10.13189/ujer.2020.081132.
\end{abstract}

(b): Siti Zuhriyah, Bambang Widi Pratolo (2020). Exploring Students' Views in the Use of Quizizz as an Assessment Tool in English as a Foreign Language (EFL) Class. Universal Journal of Educational Research, 8(11), 5312 - 5317. DOI: 10.13189/ujer.2020.081132.

Copyright $\bigcirc 2020$ by authors, all rights reserved. Authors agree that this article remains permanently open access under the terms of the Creative Commons Attribution License 4.0 International License

\begin{abstract}
The existence of educational applications that have been widely used in various universities creates new learning styles. One of the most frequently used online-based learning applications is Quizizz. Nowadays, Quizizz is commonly used as an assessment tool in almost all levels of education. This study aimed to explore students' views in using Quizizz as an assessment tool in an English class. This article employed a case study as a method. A semi-structured interview was utilized to gather the data. The participants of this research were students in one of the private universities in Yogyakarta. The results revealed that some of the students' views regarding the use of Quizizz are: (1) an interesting tool, (2) encouraging students' confidence, (3) increasing students' motivation, and (4) improving reading ability. Furthermore, the students gave a positive response to the use of Quizizz in the classroom. These findings contributed to a better understanding regarding the positive response to the use of Quizizz application as an assessment tool, particularly for the Indonesian teachers. In conclusion, several findings were highlighted.
\end{abstract}

Keywords Quizizz Application, Assessment, English Class

\section{Introduction}

One of the effects of technological advances is the existence of educational applications that have been widely used in almost all levels of education. Several application tools that can be utilized as learning media to support the effectiveness of learning among others are Edmodo, Socrative, Kahoot, Schoology, and Quizizz. Furthermore, students today are the digital generation, resulting in them being familiar with the technology [1]. Moreover, the use of technology can assist the teachers in completing their tasks more efficiently and effectively. It is common for today's students to use and access the internet wherever they are.

One of the online-based learning applications commonly used is Quizizz. It can be utilized for the beginner level of elementary to college students. Through this application, students can participate in interactive classroom activities using their mobile devices to enhance their learning experience. It is such a positive thing because learning does not always use books and paper as the media. Therefore, students and teachers are no longer burdened with learning media.

Quizizz provides multi-player activities creating more interactive and fun exercises in the classroom, such as answering questions. According to Zhao [2] Quizizz is a game-like educational application. It has several features, such as memes, themes, avatars, and entertaining music, 
making it different from other educational applications. Basuki and Hidayati [3] state that Quizizz is a fun game to conduct quick assessments in the classroom. In short, it can be inferred that Quizizz is a web tool to create interactive quiz games used as an assessment instrument in the classroom.

The interactive quiz is carried out by choosing the correct answer. There are four choices displayed in four different colors consisting of red, blue, yellow, and green. The assessors can also add an image to the background of the questions. The colors, avatars, and music in the quiz provide a gaming-like learning experience for students. At the end of each question, students will find the results displayed in their devices in a meme form. "After students answer each question, Quizizz will show pictures with memes to tell whether the answer is right or wrong and this is a treat for students” [4]. Moreover, Mei, Ju, and Adam [5] assert that Quizizz rovides the data and statistics about students' performance. The assessors can analyze the number of students answering the questions and even download the statistics results in the Excel form. "The instructors can monitor the process and download the report when the quiz is finished to evaluate students' performance" [2]. Students can work on the Quizizz at the same time, and they can see the ratings result directly through the leaderboard. Thus, utilizing this application as an assessment tool will help the students to stimulate their interest and improve their engagement.

Quizizz has several features different from other applications. According to Konstantinidis, Theodosiadou, and Pappos [6] the features include: first, the Quizizz application can be set into two game models, namely in live or as homework, depending on the objectives of the assessment. If the Quizizz game is ideal for an in-class review session, then it is done in live in which it automatically ends when all students have completed it. They need to complete the game at once, and it cannot be resumed since it has a live result on the dashboard while it is running. Likewise, with Quizizz as homework, in which it is done if the task is ideal for a homework assignment. The teacher can set a deadline for up to two weeks, and students can resume a half-done assignment later. The data of both live and homework games will show up in the "My reports" tab.

Second, after being completed, the Quizizz features will show the correct answer to each question. Third, at the end of the task, it will display a review showing all the questions. Besides, the teacher can stop the timer and choose to show the leaderboard. Medvedovska [7] states that Quizizz is interesting because assessors can add music and pictures. These items will appear when the students have chosen the answer. After finishing the task, the report can be accessed and analyzed to see the overall results in the Excel format.

Chaiyo and Nokham [8] mention that the advantage of using Quizizz is that the student cannot cheat due to the random questions it provides. Therefore, they will focus more on the quiz. Lestari [9] discovered that students are more centered and mindful of the test when utilizing Quizizz. Furthermore, the students know the correct answer to each question they have completed. At the end of the session, they can find out the rank of all the students. Whereas the disadvantage of Quizizz is that students can experience a decrease in level because of the length of time affecting the results obtained. The quicker the quiz is done, the higher the results obtained. The utilization of Quizizz is dependent on an internet connection. Therefore, if the connection is weak, then it will be a problem for students to join the Quizizz session.

Assessment is a crucial process. Brookhart [10] found that assessment is a process or activity of gathering, analyzing, and interpreting information concerning the process and student learning outcomes in achieving learning objectives. It means that the assessment must be planned, gradual, and ongoing process to obtain an overview of students' development. Jimaa [11] states that the purpose of an assessment is to determine the level of progress and suitability of student learning outcomes. An assessment can diagnose students' participation in learning activities to determine their achievement in the learning process (Nurhadianti \& Pratolo, [12] ; Soifah \& Pratolo, [13].

According to James [14], there are two kinds of assessments most frequently discussed in teaching and learning, namely summative and formative. Vagholkar [15] argues that summative assessment is done at the end of learning or program. Straub, Marsh, and Whalen [16] state that summative assessment is used to determine the classification of awards in a program. According to Qu and Zhang [17], the purpose of summative assessment is to evaluate students at the end of learning. Student results are compared with several standards or benchmarks. Qu and Zhang [17] highlight several examples of summative assessments, such as the final project, midterm exam, and paper. Therefore, summative assessment is concerned with summarizing students' achievement and becoming a report at the end of a study program.

Bennett [18] defines formative assessment as a test conducted in the middle of a teaching program aiming to find out students' learning abilities. It is also a process of teaching and learning activities providing feedback, both for students and teachers. Moreover, Loyd and Koenig [19] state that the goal of formative assessment is to monitor students' learning, and it provides ongoing feedback that can be used by teachers. The aims are to improve the quality of the teacher. Whereas for the students, it can improve their learning. Formative feedback ought to be properly designed to enhance students' understanding of the topics learned. Therefore, Quizizz application can be used as a summative or formative assessment tool.

Quizizz is designed with modern technology, it is a fun multiplayer game platform for a classroom activity. It 
displays students' answers on the screen. Research on online quizzes as a teaching and assessment tool strictly concludes that the combination of quizzes with instructional activities or teaching strategies is favorable. It helps students appertain to quiz appreciation, learning effort, learning motivation, activities involvement, and academic achievement.

There has been an expanding number of studies concentrating on using application tools to support teaching and learning e.g., [2] and [5]. First, a study by Zhao [2] revealed students' feedback on using Quizizz in an accounting classroom. This study examined the effect of frequency on students' feedback and instructors' teaching evaluations through the Quizizz. The results disclosed that students realized that Quizizz could improve their learning. They assumed that Quizizz was easy to use, as an assessment tool better than using paper only, which can reduce students' anxiety during the tests.

The second study was conducted by Mei, Ju, and Adam [5]. This study investigated the effective and exciting evaluation of students by implementing Quizizz as game-based learning in the Arabic classroom of Sultan Idris Education University Malaysia. The researchers found that all students were active in answering the questions and more concentrated on the topic. Furthermore, the results of the study indicated that the students showed a positive attitude towards Quizizz as an online teaching and assessment tool.

Most of the previous research focused on effectiveness in using Quizziz as game-based learning. Although there are a handful of studies investigating the effectiveness of game-based learning in a language class, the number of studies on the implementation of the Quizziz application as an assessment tool is still limited. This research focuses on exploring the use of Quizizz application as an assessment instrument in an EFL class that had employed such an online test application several times. Students use several applications, especially Quizizz, to answer the questions created by the assessors. Providing with such application-based questions, teachers or assessors are able to assess and analyze questions items quickly and easily. Meanwhile, students became more enthusiastic about the tool. Hence, this study is intended to uncover how students view the use of Quizizz application as an assessment tool in an EFL class.

\section{Method}

This study is a case study conducted in an English class of a private university in Yogyakarta. Time and resource limitations prevented the researcher from reaching the ideal number of participant (6-10) as suggested by (Cohen, Manion and Morrison, [20]. This study used a selection of six participants hinged on the following criteria. First, students should be familiar with the Quizizz application, meaning that they have used the application for 5 to 10 times. Second, students must have taken or be taking an English subject at the time of this study being conducted.

This study employed a semi-structured interview to collect data because the researcher wanted to find out about students' views in-depth. According to Cohen, Manion, and Morisson [20], a semi-structured interview is an informally guided process where only some questions are pre-determined, and new questions are developed from the discussion. The exact wording of questions is not necessarily pre-determined. These kinds of interviews are used to understand someone's impressions or experiences.

The researcher prepared a recorder in the interview session to record the participants' information to obtain precise data. For ethical consideration, prior to the interview, they were informed that any data resulting from the interview would be kept securely in a specific computer folder and determined as soon as the research ended. The researcher also informed that participants' names would not be used throughout this study to ensure their privacy. The Indonesian language was used during the interview to comfort and ease the participants.

The data were processed by converting the audio into written data through the transcription process. Then, the researcher conducted the data coding process, as suggested by Weston et al. [21]. First, the process involved reading the raw transcription consisting of many pages. Secondly, the transcript was split up into smaller segments to identify exciting information related to the topic. Following this, the researcher established the underlined points, which were to act as the initial labels. The next steps were identifying similar codes and clustering them into fewer codes. Finally, the codes were reduced again to create broader categories, known as themes.

\section{Finding and Discussion}

This section describes the findings of students' views towards the use of Quizizz application as an assessment tool in an English class. Several relevant works of literature also support this finding. Additionally, the results of the participants' interviews were cited to substantiate the findings of this study.

\section{Students' Views on the Use of Quizizz}

The attitudes of students regarding the use of Quizizz as an assessment tool are as follows: (1) They considered Quizizz as an interesting tool, (2) It encouraged their confidence, (3) It increased their motivation, and (4) It improved their skills. The researcher examined the results for each category within the following subsections.

\section{An Interesting Tool}

The data show that 5 of 6 participants highlighted that the use of Quizizz as an assessment tool was interesting. 
For them, as long as they used Quizizz, they felt interested due to the many features it provided having benefits for them.

$$
\begin{aligned}
& \text { "It is an interesting application for students' } \\
& \text { assignments because they can answer the questions } \\
& \text { without having to ask a friend" (Participant 3) } \\
& \text { "Based on my experience, using Quizizz is interesting } \\
& \text { because it is an online application" (Participant 4) } \\
& \text { "Using Quizizz is interesting. It helps the teacher to } \\
& \text { conduct the test easily" (Participant 5) }
\end{aligned}
$$

Based on the data above, the use of Quizizz as an assessment tool received a positive response from the students as they assumed that it was interesting. Zhao [2] mentions that Quizizz is a game-based learning application that makes interesting and fun exercises in class. Furthermore, it can be designed in different formats, such as true or false and multiple-choice, as if it was a game. Mac Namara and Murphy [22] state that the concept of gamification has been applied in educational applications, namely Quizizz. After answering all questions, students will be given prizes through memes appearing along with the results of the answers, which can be right or wrong. Thus, students will be interested in doing their assessment and motivated to participate in teaching and learning in the classroom.

\section{Encouraging Students' Confidence}

Another finding of students' perception on the use of Quizizz as an assessment tool in an EFL class is that they assumed that it could encourage their confidence. The following statements are derived from the interview.

"Through Quizizz, students become more confident about the results displayed" (Participant 2)

"Quizizz also improves students' self-confidence. If shy students got a good score, then they will be encouraged to participate in the learning process" (Participant 6)

It can be inferred that students were more confident when they used Quizizz as an assessment tool. Moreover, it also provided an avatar feature being the profile of each student. Each avatar is different from others. Zhao [2] asserts that Quizizz is a colorful application having an avatar and music causing the students to have the same experience as playing a game. After answering all questions, a picture or meme will appear to inform whether the answer is true or false. Students are allowed to change their names to anonymous and have a funny profile. It aims to create an enjoyable situation and anticipate their anxiety when they do an assessment. Pitoyo, Sumardi, and Asib [23] state that game-based scoring systems, such as Quizizz, can produce positive psychological useful to encourage their confidence and minimize their anxiety. Hence, students become more confident in using Quizizz application as an assessment tool.

\section{Increasing Students' Motivation}

Some of the participants agreed that Quizizz was able to increase their motivation. The following statements are taken from the interview.

"Quizizz provides a description of the correct and incorrect answers that motivates me to do the assessment. Thus, students can understand their mistakes" (Participant 1)

"Quizizz reveals the correct answers. Therefore, students can revise, understand their mistakes, and find out the best results from each quiz. These things are able to increase students' motivation" (Participant 5)

"One of the advantages of using Quizizz is that students can be motivated to revise the wrong answers. Hence, it is called by self-evaluation" (Participant 6)

The interview revealed that the feedback in the Quizizz application eased the students to revise the answers to the questions that have been completed. In other words, it gives students a second chance to correct their mistakes. This feature motivates students to analyze the dubious or incorrect answers. Chaiyo and Nokham [8] state that the use of Quizizz will support students in learning and increase their engagement, enjoyment, concentration, and motivation in the classroom. Moreover, Licorish et al. [24] found that students' motivation and learning experience will increase through the Quizizz learning platform.

Regardless of the feedback feature, Quizizz is also considered as one of the new learning styles.

"For me, Quizizz gives me a new learning style and motivates me in learning” (Participant 4)

In general, students tend to focus only on the questions written on the paper when they do the assessment. It is considered as a traditional method, which seems monotonous for students. Wihartanti et al. [25] assert that the use of media, such as smartphones, will be more beneficial than traditional learning as students' involvement and motivation in learning will increase. Therefore, it is a must for the assessors to understand the new learning trends or styles, especially in making questions more interesting and not monotonous.

\section{Improving Reading Ability}

All participants agreed that the use of Quizizz was able to improve and develop their reading skills, as stated in the following statements.

"My reading ability increases through the use of Quizizz” (Participant 2)

"Based on my experience, I think my reading ability improves as I use Quizizz" (Participant 4)

"The most prominent ability when taking a test through Quizizz is reading. The use of the skimming method is required in Quizizz" (Participant 5) 
In using Quizizz, students are required to read and answer the questions based on the time determined by the assessors. Thus, they have to read quickly using the skimming method. It is in line with what Priyanti, Santosa, and Dewi [26] argued that the use of Quizizz results in a better reading comprehension achievement than the conventional teaching strategy. Besides, Rraku [27, 28] asserts that skimming the text aims to grasp the main idea, identify the text structure, and confirm the readers' predictions.

\section{Conclusions}

The results of the study uncover four findings. First, it is clear that students viewed Quizizz as an effective and interesting application tool to do the assignment in an English class at a university level, as they did not feel bored and could control their focus while doing the assignment or assessment. Second, the use of Quizizz encouraged their confidence. As their profiles could be anonymous, it increased their confidence. Third, it was able to increase their motivation. The feedback feature in Quizizz motivated them to revise and understand the errors of the selected answers. Fourth, it improved their reading ability. The use of the skimming method in reading is required in using the Quizizz. In this study, they used the skimming strategy to identify the point of each question. At last, this study implies that an English teacher may consider Quizz as an alternative to assess the students in a fun way and at the same time motivate them to study even harder.

\section{REFERENCES}

[1] Sartini, S. (2020). Kahoot in maritime English teaching: Its impact on nautical science cadet's oral reproduction and vocabulary. English Language Teaching Educational Journal, 3(1), 41-51. https://doi.org/10.12928/eltej.v3i1.166 7

[2] Zhao, F. (2019). Using quizizz to integrate fun multiplayer activity in the accounting classroom. International Journal of Higher Education, 8(1), 37-43. https://doi.org/10.5430/ij he.v8n1p37

[3] Basuki, Y., \& Hidayati, Y. (2019). Kahoot! or Quizizz: the Students' Perspectives. ELLIC. https://doi.org/10.4108/eai. 27-4-2019.2285331

[4] Michelle, E., \& Lockyer, L. (2013). Tolls For Learning: Technology and Teaching Strategies. University of Wollongong Research Online, 37(9), 1480-1483.

[5] Mei, S. Y., Ju, S. Y., \& Adam, Z. (2018). Implementing Quizizz as Game Based Learning in the Arabic Classroom. European Journal of Social Sciences Education and Research, 12(1), 208.https://doi.org/10.26417/ejser.v12i1.p 208-212
[6] Konstantinidis, A., Theodosiadou, D., \& Pappos, C. (2016). Web 2.0 tools for supporting teaching. Turkish Online Journal of Distance Education, 14(4), 287-295. https://doi.org/10.17718/tojde.55896

[7] Medvedovska, D. (2016). Yulia Skarlupina Tamara Turchyna Integrating online educational applications in the classroom. European Humanities Studies.

[8] Chaiyo, y., Nokham, R. (2017). The effect of kahoot, quizizz and google forms on the student's perception in the classrooms response system. International Conference on Digital Arts, Media and Technology (ICDAMT), 178-182

[9] Lestari, T. W. (2019). Kahoot! And Quizizz: A Comparative Study On The Implementation Of E-Learning Application Toward Students'motivation. Karya Ilmiah Dosen, 2(2).

[10] Brookhart, S. M. (2012). Teacher feedback in formative classroom assessment. In Leading Student Assessment. https://doi.org/10.1007/978-94-007-1727-5_11

[11] Jimaa, S. (2011). The impact of assessment on students learning. Procedia - Social and Behavioral Sciences, 28(December 2011), 718-721. https://doi.org/10.1016/j.sbs pro.2011.11.133

[12] Nurhardianti \& Pratolo, B. W. (2020). Students' perception towards the application of kahoot as an assessment tool Universal Journal of Educational Research, 8(5), 2150-2155. doi:10.13189/ujer.2020.080554

[13] Soifah, U., \& Pratolo, B. W. (2020). Teachers'belief, implementation, and challenges in portfolio assessment in writing. Journal of Critical Reviews, 7(9), 986-990. doi:10.31838/jcr.07.09.181

[14] James, M. (2010). Educational Assessment: overview. International Encyclopedia of Education, 3(2010), 161-171. https://doi.org/10.13140/2.1.1683.0243

[15] Vagholkar, K. (2019). OSCE as a Summative Assessment Tool for Undergraduate Students of Surgery-Our Experience. Indian Journal of Surgery, 81(4), 412. https://doi.org/10.1007/s12262-018-1827-z

[16] Straub, J., Marsh, R. A., \& Whalen, D. J. (2017). Small Spacecraft Development Project-Based Learning: Implementation and Assessment of an Academic Program. Small Spacecraft Development Project-Based Learning: Implementation and Assessment of an Academic Program, 1-321. https://doi.org/10.1007/978-3-319-23645-2

[17] Qu, W., \& Zhang, C. (2013). The Analysis of Summative Assessment and Formative Assessment and Their Roles in College English Assessment System. Journal of Language Teaching and Research, 4(2), 335-339. https://doi.org/10.4 304/jltr.4.2.335-339

[18] Bennett, R. E. (2011). Formative assessment: A critical review. Assessment in Education: Principles, Policy and Practice, 18(1), 5-25. https://doi.org/10.1080/0969594X.20 10.513678

[19] Loyd, G. E., \& Koenig, H. M. (2008). Assessment for Learning: Formative Evaluations. International Anesthesiology Clinics, 46(4), 85-96. https://doi.org/10.109 7/AIA.0b013e31818623df

[20] Cohen, L., Manion, L., \& Morrison, K. (2002). Research methods in education. Routledge. 
[21] Weston, C., Gandell, T., Beauchamp, J., McAlpine, L., Wiseman, C., \& Beauchamp, C. (2001). Analyzing interview data: The development and evolution of a coding system. Qualitative Sociology, 24(3), 381-400.

[22] Mac Namara, D., \& Murphy, L. (2017). Online versus offline perspectives on gamified learning. CEUR Workshop Proceedings, 1857(May 2017), 47-52.

[23] Pitoyo, M. D., Sumardi, S., \& Asib, A. (2019). Gamification based assessment: A Test Anxiety Reduction through Game Elements in Quizizz Platform. International Online Journal of Education and Teaching (IOJET), 6(3), 456-471. Retrieved from http://iojet.org/index.php/IOJET/article/vie $\mathrm{w} / 626$

[24] Licorish, S. A., Owen, H. E., Daniel, B., \& George, J. L. (2018). Students' perception of Kahoot!'s influence on teaching and learning. Research and Practice in Technology Enhanced Learning, 13(1). https://doi.org/10.1186/s41039018-0078-8
[25] Wihartanti, L. V., Ramadhan Prasetya Wibawa, Rohana Intan Astuti, \& Pangestu, bayu aji. (2019). Penggunaan aplikasi quizizz berbasis smartphone dalam membangun kemampuan berpikir kritis mahasiswa. Prosiding Seminar Nasional Pendidikan Dan Pembelajaran 2019, 362-368.

[26] Priyanti, N. W. I., Santosa, M. H., \& Dewi, K. S. (2019). Effect of Quizizz Towards the Eleventh-Grade English Students' Reading Comprehension in Mobile Learning Context. Language and Education Journal Undiksha, 2(2), 71-80. https://doi.org/10.23887/leju.v2i2.20323

[27] Rraku. (2013). The Effect of Reading Strategies on the Improvement of the Reading Skills of Students. Studia Hmanistyczne, 7(2)

[28] Rosalina, E., \& Nasrullah, N. (2020). The Correlation between Self - Esteem and Student's Reading Comprehension. English Language Teaching Educational Journal, 2(2), 70-78. doi: https://doi.org/10.12928/eltej.v2i2 .1190 